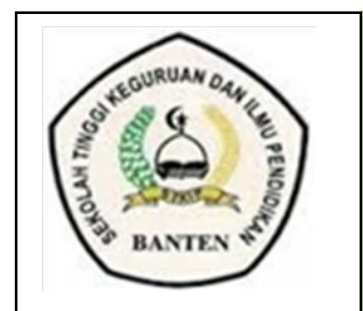

JoEE 1 (1) (2020) : 16-22

JoEE

JURNAL PENDIDIKAN GURU PENDIDIKAN ANAK USIA DINI

http://jurnal.stkipbanten.ac.id/index.php/Joe

\title{
MENINGKATKAN KEMAMPUAN MOTORIK KASAR ANAK USIA DINI MELALUI BERMAIN LEMPAR TANGKAP BOLA
}

\author{
Larasati Nur Indah Prawesti \\ iiazzprawesti@gmail.com \\ Mahasiswa Pendidikan Guru Pendidikan Anak Usia Dini \\ Pendidikan Guru Pendidikan Anak Usia Dini
}

\begin{abstract}
Abstrak
Tujuan penelitian ini adalah untuk mengetahui peningkatkan kemampuan Motorik Kasar Anak Usia Dini Melalui Bermain Lempar Tangkap Bola. Penelitian yang peneliti lakukan ini berupa penelitian studi literature atau studi kepustakaan yang terdiri sumber primer dan sekunder. Berdasarkan hasil penelitian yang dilakukan oleh peneliti berupa sumber yang relevan sumbernya melihat dari sumber primer yang terdiri dari buku skripsi dan jurnal berupa buku, skripsi dan jurnal yang mengacu pada permainan lempar tangkap bola. pernyataan ini didukung oleh peneliti terdahulu yang dapat meningkatkan kemampuan motorik kasar anak usia dini melalui bermain lempar tangkap bola.
\end{abstract}

Kata Kunci: Motorik kasar. Lempar tangkap bola

\section{PENDAHULUAN}

\section{Latar Belakang}

Pendidikan adalah proses mengubah diri menjadi lebih baik lagi dan dewasa dalam segala urusan dan tanggung jawab melalui pengajaran dan pelatihan. Dalam pendidikan pembelajaran yang langsung maupun tidak langsung, sengaja maupun tidak disengaja untuk melakukan kegiatan di dalam ruangan maupun ruang terbuka untuk mendapatkan suatu pengetahuan yang diharapkan untuk bekal di masa depan. Oleh sebab itu pendidikan tidak hanya disekolah saja, melainkan bermain juga termasuk belajar. Ketika kita masih bayi, kita di ajarkan untuk berjalan dengan orang tua itupun termasuk pendidikan dan sudah dewasa pun kita masih diajarkan pendidikan oleh guru, pendidikan itu tidak hanya sampai dewasa saja melainkan hingga akhir hayat.

Dengan dasar itu pendidikan menjadi hal yang utama dalam membentuk karakter anak terlebih anak masih usia dini. 
Pengertian pendidikan menurut Undang-undang sistem Pendidikan Nasional No.20 Tahun 2003 adalah usaha sadar dan terencana untuk mewujudkan suasana belajar dan proses pembelajaran agar peserta didik secara aktif untuk mengembangkan potensi dirinya untuk memiliki kekuatan spritual keagamaan, pengendalian diri, kepribadian, kecerdasan, akhlak mulia, masyarakat bangsa dan negara. Hal serupa menurut undang-undang sistem Pendidikan nasional No.20 Tahun 2003 bab 1 pasal 1 ayat 14 upaya pembinaan yang ditujukan pada anak sejak lahir sampai dengan usia enam tahun yang dilakukan melalui pemberian rangsangan pendidikan untuk membantu pertumbuhan dan perkembangan jasmani dan rohani agar anak memiliki kesiapan dalam memasuki pendidikan lebih lanjut pengertian anak usia dini.

Pendidikan Anak Usia Dini merupakan pendidikan yang tidak terlepas dari kegiatan bermain. Apapun kegiatan belajar anak pasti dilakukan dengan bermain, karena dengan bermain dapat merangsang/menstimulus pertumbuhan dan perkembangan anak. Belajar sambil bermain merupakan sarana utama yang dapat digunakan anak untuk meningkatkan perkembangan motoriknya. Hal serupa juga dikemukakan oleh filsuf yunani yaitu plato bahwa orang pertama yang menyadari dan melihat praktis dari bermain, karena bermain dapat digunakan sebagai media untuk meningkatkan keterampilan dan kemampuan tertentu pada anak.

Lempar tangkap bola merupakan kegiatan bermain yang menggunakan bola sebagai media. Kegiatan lempar tangkap bola ini seringkali diterapkan bagi anak usia dini dengan tujuan untuk mengembangkan motorik kasar. Penelitian ini menggunakan media bola kecil yang ringan dan tidak memberatkan bagi anak dalam bermain lempar tangkap bola. Permainan dalam dunia anak merupakan hal yang menyenangkan serta membahagiakan untuk menambah wawasan baru. Karena lewat permainan anak dapat berkembang sesuai dengan kebutuhannya. Permainan merupakan kegiatan yang menyenangkan untuk anak dan lebih mudah memahami materi serta cenderung tidak menyadari bahwa anak sedang belajar. ${ }^{1}$ Permainan juga dapat meningkatkan hubungan anatara anak bagi di dalam kelas maupun di luar kelas.

Gerak lokomotor yaitu meliputi gerak tubuh yang berpindah tempat, seperti berjalan, berlari, melompat. Gerak nonlokomotor yaitu menggerakan anggota tubuh dengan posisi tubuh diam di tempat seperti mengangkat, memutar, mendorong. keterampilan ini sering dikaitkan dengan keseimbangan atau kestabilan tubuh, yaitu gerakan yang membutuhkan keseimbangan pada saraf tertentu. Gerak manipulatif, meliputi pengguna serta pengontrolan gerakan otot-otot kecil yang terbatas terutama yang berada di tangan dan kaki. $^{2}$

\section{Rumusan Masalah}

Bagaimana

peningkatan kemampuan motorik kasar anak usia dini melalui permainan lempar tangkap bola?

\footnotetext{
${ }^{1}$ Ni Luh Ayu Cahyani, MG Rini Kristiantari, I.B. Surya Manuaba. 2014. Model Pembelajaran Quantum Melalui Permainan Tradisional Untuk Meningkatkan Kognitif Anak Kelompok B Tk Kumara Jaya Denpasar. e-Journal PG-PAUD, Volume 2 No.1 2014

${ }^{2}$ Montolalu (2012). Bermain dan Permainan Anak. Penerbit Universitas Terbuka. Hal. 4.22
} 


\section{Tujuan Penelitian}

Meningkatkan

kemampuan

Motorik Kasar Anak Usia Dini Melalui

Bermain Lempar Tangkap Bola.

\section{METODE}

Jenis penelitian ini adalah Penelitian Studi Literatur. Studi literatur dilakukan dengan cara mempelajari dan mengkaji buku-buku yang ada hubungannya dengan masalah yang diteliti untuk memperoleh bahan-bahan atau sumber informasi tentang masalah yang diteliti. Teknik pengumpulan data yang digunakan yaitu sumber data primer dan sumber data sekunder. Data primer penelitian ini adalah menggunakan data dari jurnal dan skripsi terdahulu, sedangkan data sekundernya adalah dari buku-buku.

\section{HASIL DAN PEMBAHASAN}

\section{Hasil Penelitian}

Pada masa usia dini atau masa kanak-kanak merupakan masa yang paling tepat untuk mempelajari keterampilan motorik jika dibandingkan dengan masa remaja dan dewasa. Pada penelitian ini yang dimaksud dengan motorik kasar adalah kemampuan yang membutuhkan koordinasi bagian tubuh anak seperti tangan, dan aktivitas otot kaki dalam menyeimbangkan tubuh serta kekuatan tangan dan kaki saat melempar dan menangkap bola.

Lempar tangkap bola merupakan kegiatan bermain yang menggunakan bola sebagai media. Kegiatan lempar tangkap bola ini seringkali diterapkan bagi anak usia dini dengan tujuan untuk mengembangkan motorik kasar. Penelitian ini menggunakan media bola kecil yang ringan dan tidak memberatkan bagi anak dalam bermain lempar tangkap bola. Permainan dalam dunia anak merupakan hal yang menyenangkan serta membahagiakan untuk menambah wawasan baru. Karena lewat permainan anak dapat berkembang sesuai dengan kebutuhannya.

\section{1) Peningkatan Kemampuan Motorik Kasar Dalam Bermain Lempar Tangkap Bola}

Berdasarkan analisis di tingkat TK terlihat masih ada beberapa siswa yang belum mampu dalam motorik kasarnya terutama dalam bermain lempar tangkap bola. Hal tersebut terlihat pada saat guru melempar bola anak belum merespon untuk menangkapnya dan adapula anak yang merespon akan tetapi belum maksimal dalam menangkapnya, dengan demikian dalam bermain sebuah permainan lempar tangkap bola ini butuh konsentrasi sehingga anak belum mampu untuk melakukannya sehingga menyebabkan motorik kasar tidak berkembang.

Pengambilan dan pengumpulan data dilakukan melalui kajian terhadap pustaka primer yang dihimpun oleh peneliti. Hasil penelitian yang didapatkan adalah terdapat 2 skripsi dan 3 jurnal yang berkaitan dengan motorik kasar anak usia dini melalui bermain lempar tangkap bola. Data dari sumber primer ini disajikan kembali dengan cara deskriptif kualitatif dan kuantitatif.

Berikut ini adalah deskripsi dari sumber pustaka primer lain yang 
berhubungan dengan tema penelitian ini, diantaranya adalah :

1. Rifka Toyba Humaida (2019) dalam skripsi program studi Pendidikan Islam Anak Usia Dini. Fakultas Tarbiyah dan Keguruan UIN Raden Intan Lampung, yang berjudul Mengembangkan Kemampuan Motorik Kasar Anak Melalui Bermain Lempar Tangkap Bola Di Taman Kanak-kanak Aisyiyah 3 Bandar Lampung.

2. Maysyah Hafifah (2016) dalam jurnal program studi PG PAUD FIP UNY, yang berjudul Meningkatkan Keterampilan Motorik Kasar Melalui Bermain Lempar Tangkap Bola Kelompok Al Di TK ITQ AL Ikhlas Sawangan Magelang.

3. Hesti Wijayanti (2014) dalam skripsi Program Studi Pendidikan Guru Pendidikan Anak Usia Dini Jurusan Pendidikan Pra Sekolah dan Sekolah Dasar. Fakultas Ilmu Pendidikan Universitas Negeri Yogyakarta, yang berjudul Peningkatan Kemampuan Motorik Kasar Anak Melalui Bermain Lempar Tangkap Bola Besar Kelompok B TK Al Hidayah Semawung Bnajaroyo Kali bawang Kulonprogo.

4. Syamsidar (2018) dalam jurnal Program Studi PG PAUD Fakultas Keguruan dan Ilmu Pendidikan. Universitas Muhammadiyah Palu, yang berjudul Meningkatkan Kemampuan Motorik Kasar Anak
Melalui Bermain Lempar Tangkap Bola Besar Kelompok B1.

5. Astuti, Dorce Banne Pabunga, Ahid Hidayat (2019) dalam jurnal Program Studi PG PAUD. Universitas Halu Oleo. Jln. H.E.A Mokodompit Kendari, yang berjudul Meningkatkan Kemampuan Motorik Kasar Anak Melalui Kegiatan Bermain Lempar Tangkap Bola Plastik.

\section{2) Kelebihan dan Kekurangan Dalam Bermain Lempar Tangkap Bola}

Adapun kelebihan dan kekurangan dalam bermain lempar tangkap bola adalah :

a. Kelebihan

1. Bahan mudah didapatkan.

2. Anak merasa senang dan memberikan pengalaman belajar yang menarik bagi anak tanpa adanya paksaan.

3. Melatih percaya diri anak.

4. Menjaga kesehatan.

5. Meningkatkan aktivitas berkomunikasi dan berinteraksi satu dengan yang lain.

b. Kekurangan

1. Membutuhkan ruangan yang luas

2. Anak yang berkebutuhan khusus, yang dimaksud anak berkebutuhan khusus iyalah anak yang mempunyai kekurangan dalam mentalnya karena menyangkut dengan IQ anak

Dengan bermain lempar tangkap bola dapat merangsang 
aspek perkembangan motorik kasar anak. Pada saat anak merasa senang maka pembelajaran yang diberikan oleh guru akan lebih mudah untuk diterima.

\section{Pembahasan}

\section{Lempar tangkap bola sebagai stimulus perkembangan gerak motorik}

Ada banyak cara untuk menstimulasi perkembangan motorik anak. Beberapa cara ini bisa membantu merangsang perkembangan motorik anak. Perkembangan motorik merupakan aspek perkembangan penting yang harus distimulasi pada anak. Ini karena nantinya dapat menentukan keterampilan anak dalam bergerak dan melakukan aktivitas fisik di kehidupan sehari-harinya. Selain itu, perkembangan motorik meliputi pertumbuhan dan penguatan tulang, otot, dan kemampuan anak untuk bergerak dan menyentuh sekitarnya.

Karakteristik motorik kasar anak usia dini yaitu:

a. Melakukan berbagai kegiatan terkoordinasi secara terkontrol, seimbang dan lincah

b. melakukaan kegiatan yang menunjukkan anak mampu melakukan gerakan mata, tangan, kaki, kepala secara terkoordinasi dalam menirukan berbagai gerakan yang teratur (missal: bermain lempar tangkap bola)

c. Melakukan kegiatan yang menunjukkan anak mampu melakukan permainan fisik dengan aturan d. Melakukan kegiatan yang menununjang anak mampu terampil menggunakan tangan kanan dan tangan kiri dalam berbagai aktivitas. Indikator dalam kemampuan motorik kasar anak di atas dapat dikembangkan melalui bermain Motorik kasar dapat dilihat dari delapan indikator yaitu naik:
a. turun tangga
b. melompat
c. berlari
d. melakukan gerakan tubuh secara terkoordinasi untuk melatih kelenturan, keseimbangan, dan kelincahan
e. melakukan koordinasi gerakan mata-kaki tangan-kepala dalam menirukan tarian atau senam
f. melakukan permainan fisik dengan aturan
g. terampil menggunakan tangan kanan dan kiri
h. melakukan kegiatan kebersihan diri. $^{3}$

\section{Bermain Dengan Media Pembelajaran}

Metode bermain sambil belajar dengan pusat kegiatan (sentra) dapat mengarahkan anak untuk menemukan potensi dan kecerdasan yang dimiliki. Metode tersebut cukup efektif dalam membantu anak usia prasekolah dalam belajar. Fase belajar tingkat pertama ini merupakan tahap pengenalan halhal yang baru kepada anak, maka berilah penjelasan secara sederhana, mudah dimengerti. Bila menjelaskan

\footnotetext{
${ }^{3}$ Umar Sulaiman, dkk. (2019) Tingkat Pencapaian Aspek Perkembangan Anak Usia 5-6 Tahun Berdasarkan Standar Nasional Pendidikan Anak Usia Dini. Hal. 55
} 
sesuatu yang sulit atau abstrak, berikanlah contoh konkret yang sering ditemui oleh anak dalam kehidupan sehari-hari. Hindarilah pemakaian istilah asing yang sulit dimengerti. ${ }^{4}$

\section{PENUTUP}

\section{Simpulan}

Berdasarkan dari penelitian yang telah dilakukan oleh peneliti dengan menggunakan metodologi literatur, dari berbagai sumber penelitian maka dapat ditarik kesimpulan sebagai berikut :

1. Adanya bermain lempar tangkap bola bertujuan untuk meningkatkan kemampuan motorik kasar anak usia dini dengan cara memberikan motivasi pada diri anak dan juga memberikan kesempatan kepada anak untuk melakukan kegiatan satu persatu.

2. Dengan bermain lempar tangkap bola ini, siswa dilibatkan secara langsung dalam proses belajar, akan lebih menarik dan membuat lebih aktif sehingga siswa akan lebih mudah menerima materi yang disampaikan.

3. Berdasarkan hasil penelitian yang dilakukan oleh peneliti berupa sumber yang relevan sumbernya melihat dari sumber primer yang terdiri dari buku skripsi dan jurnal berupa buku, skripsi dan jurnal yang mengacu pada permainan lempar tangkap bola. pernyataan ini didukung oleh peneliti terdahulu yang dapat meningkatkan kemampuan motorik kasar anak usia dini melalui bermain lempar tangkap bola.

\footnotetext{
${ }^{4}$ Yanuar Kiram. (2019). Belajar Keterampilan Motorik. Jakarta: Prenamedia Group. Hal. 55-56
}

\section{Saran}

Berdasarkan penelitian yang telah dilakukan, maka dapat peneliti sarankan kepada pihak-pihak yang terkait diantaranya :

1. Bagi guru, disarankan guru diharapkan dapat lebih inovatif dan kreatif dalam memberikan permainan yang bermakna bagi anak, memilih alat permainan yang menyenangkan agar anak merasa bosan dalam mengikuti pembelajaran.

2. Bagi sekolah, disarankan lebih memperhatikan kemampuan motorik anak, diadakannya media karena dengan adanya media anak lebih cepat memahami maksud guru dan anak usia dini cara berfikirnya kongkrit dengan melihat benda-benda yang ada disekitarnya.

3. Bagi peneliti, diharapkan dapat menjadikan hasil penelitian ini sebagai referensi untuk melakukan penelitian yang lebih baik lagi dengan menggunakan kegiatan bermain yang lebih menarik dalam mengembangkan kemampuan motorik kasar anak usia dini melalui bermain lempar tangakap bola.

\section{DAFTAR PUSTAKA}

Setiawan, M. H. Y. (2016). Melatih Keterampilan Sosial Anak Usia Dini Melalui Permainan Tradisional. Jurnal Dimensi Pendidikan dan Pembelajaran, vol.5 Januari 2016

Khasanah, I., Prasetyo, A., \& Rakhmawati, E. (2011). Permainan Tradisional Sebagai Media Stimulasi Aspek Perkembangan Anak Usia Dini. 
Jurnal Penelitian PAUDIA, Vol.1 No. 1 2011

Cahyani, N. L. A., Kristiantari, M. R., \& Manuaba, I. B. S. (2014). Model

Pembelajaran Quantum Melalui

Permainan Tradisional Untuk

Meningkatkan Kognitif Anak Kelompok B Tk Kumara Jaya Denpasar. e-Journal PGPAUD, Volume 2 No.1 2014

Charles, A. G., Abdullah, M. R, dkk (2017). the Effect of Traditional Games Intervention Programme in the Enhancement School-Age Children 'S Motor Skills : a Preliminary Study. Movement, Health \& Exercise, 6(2).

Montolalu (2012). Bermain dan Permainan Anak. Penerbit Universitas Terbuka

Sujiono Bambang, dkk. (2012). Metode Pengembangan Fisik. Penerbit Universitas Terbuka

Aisyah Siti, Tatminingsih Sri, dkk. (2014). Perkembangan dan Konsep Dasar Pengembangan Anak Usia Dini. Penerbit Universitas Terbuka

Umar Sulaiman, dkk. (2019)

Tingkat Pencapaian Aspek Perkembangan Anak Usia 5-6 Tahun Berdasarkan Standar Nasional Pendidikan Anak Usia Dini. Indonesian Journal of Early Childhood Education Volume 2, Nomor 1, Juni 2019

Walujo Adi Djoko\& Anies Listyowati. (2017). KOMPENDIUM $P A U D$. Depok: Prenamedia Group
Sujiono Bambang, dkk. (2012). Metode Pengembangan Fisik. Penerbit Universitas Terbuka

Diantama Suarifqi. (2018). Metode Penelitian Pendidikan. Bandung: Pustaka Rahmat

Andriani Durri, dkk. (2014).

Metode Penelitian. Penerbit Universitas Terbuka

Alvan Hazhari, dkk (2019). The Effect of Playing Mpa'a Tapa Gala Game Toward Gross Motor Development on Early Childhood. Journal of Primary Education 8 (2) (2019) : $117-126$ 